\title{
Neuro-Psycholinguistic Study of Political Slogans in Outdoor Advertising*
}

\section{Нейропсихолінгвістичне дослідження політичних гасел із зовнішньої реклами**}

\author{
Serhii Maksymenko ${ }^{1}$ \\ Dr. in Psychology, Professor, \\ Active member of the National \\ Academy of Sciences of Ukraine
}

\author{
Сергій Максименко ${ }^{1}$ \\ доктор психологічних наук, \\ професор, \\ дійсний член НАПН України
}

\section{E-mail: 244-19-63@mail.ru \\ orcid.org/0000-0002-3592-4196}

Bohdan Tkach ${ }^{1}$

Dr. in Psychology,

Senior Researcher
Богдан Ткач ${ }^{1}$

доктор психологічних наук, старший науковий співробітник

E-mail: bohdan.tkach@gmail.com orcid.org/0000-0003-0895-7192

\section{Lesia Lytvynchuk ${ }^{2}$}

Dr. in Psychology,

Senior Researcher

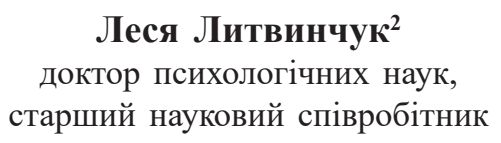

E-mail: lutol@ukr.net

orcid.org/0000-0002-5085-4499

* This research was funded by the Ministry of Education and Science of Ukraine, RN 0118 U003098

** Дослідження виконане за фінансової підтримки Міністерства освіти і науки України, Реєстраційний номер $0118 \mathrm{U} 003098$ 
Neuro-Psycholinguistic Study of Political Slogans in Outdoor...

Liana Onufriieva ${ }^{3}$

Ph.D. in Psychology,

Assistant Professor,

Head of the Department of General and Applied Psychology
Ліана Онуфрісва ${ }^{3}$

кандидат психологічних наук, доцент,

завідувач кафедри загальної та

практичної психології

E-mail: kpnu_lab_ps@ukr.net orcid.org/0000-0003-2442-4601

Researcher ID: R-5598-2018

${ }^{1}$ G.S. Kostiuk Institute of Psychology

of the National Academy of

Pedagogical Sciences of Ukraine

2, Pankivska Str., Kyiv,

Ukraine, 01033

${ }^{2}$ National Academy of the State

Border Guard Service of Ukraine named after Bogdan Khmelnitsky

46, Shevchenko Str., Khmelnitsky,

Ukraine, 29001

${ }^{3}$ Kamianets-Podilskyi National Ivan Ohiienko University

61, Ohiienka Str., Kamianets-

Podilskyi, Khmelnytskyi Reg.,

Ukraine, 32300
${ }^{1}$ Інститут психології

ім. Г.С. Костюка НАПН Украӥни

$\bowtie$ вул. Паньківська, 2, м. Київ,

Україна, 01033

${ }^{2}$ Національна академія Державної прикордонної служби України імені Богдана Хмельницького

$\square$ вул. Шевченка, 46,

м. Хмельницький, Україна, 29001

${ }^{3}$ Кам'янеиьь-Подільський начіональний університет

імені Івана Огієнка

вул. Огієнка 61, Кам'янець-

Подільський, Хмельницька обл., Україна, 32300

Original manuscript received December 20, 2018

Revised manuscript accepted September 15, 2019

\section{ABSTRACT}

Introduction. The article presents the results of a neuropsychological study in outdoor advertising. Diagnostic capabilities of the neurointerface to evaluate the efficiency of passwords are considered. The leasing process and existing methods of performance evaluation are highlighted. The specificity of neuropsycholinguistics in the approach to the analysis of the mental activity of the individual in the acquisition and use of language is shown. The ultimate goal of this neuropsycholinguistic study is to find out what exactly pleases the voter and what prompts the candidate to support the electorate of a particular region, which in turn will allow him to adjust the content of political advertising by making it highly effective.

Methods and Techniques of the Research. The EMOTIV Epoc + mobile 14 channel neurointerface was used to study the neuropsychological study of political slogans 
from outdoor advertising. In addition, we have used professional EEG monitoring software to visualize brain electrical activity and to transform transformed EEG indicators in the form of basic cognitive-emotional indicators: EmotivPRO and EMOTIV Brain Activity Map. Ranking of slogans on the effectiveness of influence on the electorate was carried out on the basic raw EEG data and their transformation into cognitive-emotional indicators: stress, interaction, interest, excitement, concentration, relaxation. This set of neuropsychological techniques is a relevant highlight. The poll was attended by potential voters in the 2019 presidential election. The sample size is 30 men and 30 women.

Results. As a result of a neuropsychological study of political slogans on outdoor advertising, it was found out which slogans are the best, good, mediocre, ambiguous, ineffective, ineffective and negative for voters. The results of the study were published on November 16, 18 on the social network "Feusbuk» and November 20, 18 on the TV channel "True here» in the broadcast "In the field of excitement» issue No 24.

Conclusions. Summarizing the findings and interpreting the cognitive-emotional indicators, it was concluded that in order to create an effective psychological impact on the voter's behavior, it is recommended to have the word "Ukraine» in the slogan, to avoid the motivating words (for women, it is the army and everything related to violence and death, and for men everything related to the provision of material goods), the use of religious sentimentality in women, and gender mainstreaming when targeting slogans.

Key words: political advertising, slogan, user experience, subconscious reactions, neuropsycholinguistics, neurointerface, cognitive-emotional indicators, electorate.

\section{Вступ}

Актуальною проблемою у психолінгвістиці $\epsilon$ вивчення взаємовідношення мови, мислення і свідомості у індивідів, які відносяться до різних субетносів та різних соціальних прошарків, a особливо у певний знаковий період буття суспільства. Коли оцінка сприйняття людьми реклами, зокрема, політичної реклами часто залежить від контексту обставин та суспільних процесів. Для соціальних інженерів важливо знати? чи створені ними політичні ідеї, які втілені у гаслах і лозунгах викликають для них бажаний ефект: спонукання до певної дії та уніфікація світогляду. Крім того, важливим стає врахування мовного розвитку певних груп людей, зокрема тих хто буде голосувати вперше. Як відомо, політична ідея - це «інтелектуальний товар» політика, який ним (чи його командою) створюється для поширення серед електорату. Політична ідея реалізується у формі лозунгів і гасел. Лозунг - лаконічне 
звернення, що відображає провідну ідею чи вимогу. Гасло лаконічна фраза, що висловлює суть повідомлення.

Для створення оригінальних, ефектних та ефективних гасел, які будуть спонукати виборців проголосувати саме за певного політика (чи партію), як правило, залучаються 3 різною компетенцією фахівців - бригаду політтехнологів. До складу даної бригади переважно входять: міфодизайнер, філософ, психолог, психолінгвіст, соціолог та маркетолог. Бувають ситуації коли функцію всієї бригади політтехнологів виконує одна особа, яка відповідальна за ідеологічну роботу у партії. Проте $\epsilon$ комерційні компанії, що спеціалізуються на психологічному консалтингу.

Основою для створення гасел $\epsilon$ : 1) свіжа аналітика про вподобання та очікування електорату, 2) тенденції попередніх виборів, 3) світові тенденції, 4) віра у всесильність політтехнологів, 5) епістемологічний підхід, 6) розраховують на вдачу.

Найбільшою проблемою $є$ відсутність швидкої, завчасної й дешевої оцінки ефективності гасел серед електорату, тому що вивчення зв'язку між мовними повідомленнями і характеристиками учасників комунікації є надзвичайно важлива, тобто трансформація намірів спікера в повідомлення i інтерпретація їх слухачами. Зрозуміло, що ефективності цієї комунікації точно буде відомо після оголошення результатів виборів ЦВК. Існують партії, які повністю довіряються «професіоналізму» іменитого політтехнолога i не здійснює перевірки ефективності гасел. Як показує багатолітній досвід, фахівець є людиною і може передбачити поведінку людей, i електорату зокрема, на середньотермінову перспективу лише на 8\%. Поведінка виборця залежить від таких чинників: 1) індивідуальнотипологічних особливостей, 2) поточного емоційного стану, 3) обставин контексту (Ткач, 2018). Під індивідуально-типологічні особливості можна створити бажаний прототип політика і завдяки мікротаргетингу, якщо $є$ біг дейт. Тоді як соціальним інженерам досить важко і фінансово затратно тотально контролювати поточний емоційний стан та обставини контексту, в яких перебуває електорат. Ще важче передбачити тактику та стратегію конкурентів по виборах.

Натомість, існують кандидати та партій, які перш ніж витратити дуже величезну суму коштів у власну рекламу, здійснюють оцінку ефективності створеної медіапродукції. Переважно для цього використовують соціологічні дослідження. Проте найбільшою 
проблемою їхньої валідності $\epsilon$ не репрезентативність вибірки, а те, що люди до кінця самі не розуміють, що саме їм подобається і часто дають соціально схвальні відповіді, особливо коли це фіксується. Інші ж кандидати та партії використовують фокусгрупи. Проте на фокус-групах через резонерство, податливість та емпатійність учасників рівень брехливості починається 3 30\% i вище. Тому результати також не точні, але інколи дозволяють прояснити ситуацію і привернути увагу політтехнологів до певних соціальних настроїв.

Беззаперечно, семантичний диференціал має своє місце для побудови суб'єктивних семантичних просторів у дослідженнях, пов'язаних зі сприйняттям політичних гасел, 3 аналізом прагматичних і конотативних значень слів, особистісних смислів (Засєкіна \& Засєкін, 2008). Проте, чи здатен він дати вичерпну відповідь на питання: «Досліджуванні дають відверті відповіді чи соціально прийнятні та узгоджені із домінуючою ідеологією у суспільстві?». Крім того D. Westen (2007) зазначає, що люди у рішеннях пов'язаних із політикою частіше роблять емоційні вчинки, а не раціональні. На це питання може дати відповідь дослідження «досвід користування» - User Experience. Це фіксація високоточною апаратурою підсвідомих реакцій людей на аудіовізуальні та інші подразники з метою виявлення, що насправді відчуває людина при користуванні продуктом/інформацією (Absher \& Cloutier, 2016). Основними об'єктами дослідження є увага, враження, емоції та користь, отримані від взаємодії 3 продуктом/інформацією (Nobre \& Kastner, 2014). Хоча «досвід користування» $\epsilon$ серйозною методологічною базою, проте варто наголосити, що він має суб'єктивний характер і може змінюватись з часом при зміні обставин контексту та появі нових конкуруючих продуктів/інформації.

У виборчих кампаніях в Україні, можливо, через брак належних знань у керівників штабів, цей метод недостатньо $є$ популярним. Для повноти, об'єктивності та неупередженості огляду проблеми варто зазначити, що в Україні $\epsilon$ компанія, яка надає послуги з об'єктивної оцінки ефективності медіапродукції - «Перша нейромаркетингова компанія України Neuro Psy Tech Group». Це свідчить, що наявна рефлексія наукового знання про мозок, психіку людини, нейроімейджінг. 
Neuro-Psycholinguistic Study of Political Slogans in Outdoor...

Метою дослідження $€$ нейропсихолінгвістичне вивчення сприйняття електоратом політичних гасел із зовнішньої реклами.

Наші завдання - по-перше, завдяки нейроінтерфейсу фіксація підсвідомих реакцій виборців на візуальне представлення політичних гасел із зовнішньої реклами; по-друге, оцінка ефектності та ефективності найпоширеніших гасел; по-третє, встановлення нейропсихолінгвістичних засобів реорганізації основних когнітивноемоційних показників для створення ефективного психологічного впливу на поведінку виборця.

\section{Методи та методики дослідження}

С.Д. Максименко (Maksymenko, 2015) зазначає, що у науковому дослідженні вибір методу $є$ вирішальною умовою теоретичної конструкції реальності та зовнішньої валідності. Поява нових високоточних нейротехногій у психолінгвістиці дало початок принципово новій епосі розвитку цієї науки - нейропсихолінгвістиці.

Складністю даної ситуації $є$ принциповій відмінності психолінгвістики та нейропсихолгінгвістики у підході до аналізу психічної діяльності суб'єкта/особистості у засвоєнні та використанні мови.

У нейропсихолінгвістиці не «суб’єкт», а «особистість», яка використовує мову, людина не «як така», а «конкретна особистість» зі своїми нейропсихологічними особливостями (Максименко \& Орап, 2018).

Нейропсихологія намагається збагнути не лише концепт відображення у психіці сущого і мовного вираження, а й дуже загальні концепти, такі як ідентичність/схожість, відмінність/ несхожість, які застосовують до всього, що існує. Тобто, зрозуміти сутність такого феномена, як свідомість (Dehaene, 2014).

У кожної людини структура мозку $\epsilon$ неповторною. Адже мозок це наймінливий $\mathrm{i}$ дуже варіативний орган. На наше переконання не зовсім коректним є опиратися виключно на дані функціональної магнітно-резонансна томографія, що дозволяє виміряти гемодинамічні реакції мозку. На основі цих реакцій можна припустити про причетність певної ділянки мозку до конкретного психічного процесу пов'язаного, мисленням та 3 мовленням. 
Цей метод нейровізуалізації дозволяє виявити значні за розміром об'єкти та зміни у просторі черепної коробки. Проте через низьку роздільну здатність не може виявити яке це цитоархітектонічне поле чи підполе. Адже варіативність мозку у людей у деяких цитоархітектонічних полях різниться у 40 раз (Kolb \& Whishaw, 2015). Також цей метод погано фіксує початок реакції, що не дозволяє робити точну кореляцію 3 психологічними подіями i гемодинамічними реакціями у різних ділянках мозку.

Очевидно, що на даному етапі розвитку нейроімейджінгу не варто опиратися на анатомічну прив'язку до функцій, а необхідно використовувати інтегральні показники електричної активності мозку, що відображають когнітивно-емоційні показники у кожен момент дослідження. У світовій психології та маркетингу використовують нейроінтерфейси для вивчення об'єктивних реакцій людей на рекламу. В Україні ця технологія була впроваджена Б.М. Ткачем у 2017 році в Інституті психології ім. Г.С. Костюка Національної академії педагогічних наук України (Ткач, 2018).

Нейроінтерфейс дає змогу передати інформацію на пряму 3 мозку без участі м'язової системи тіла. Це практично новий/ додатковий канал прямого виходу мозку у світ і новий канал для дослідження мозку, який відкриває нову епоху у нейронауці (Churchland, 2013). Тому що досі мозок вивчали як показник його електричної активності і через слабкі обчислювальні можливості комп'ютерів не могли зіставити ЕЕГ з емоціями та прийняттям рішення (Khushaba et al., 2012). Власне нейроінтерфейс у потоці ЕЕГ розпізнає певний патерн - специфічну конфігурацію електричної хвилі, яка відповідає певній вольовій дії, тобто вольовому зусиллю (Clerc, Bougrain \& Lotte, 2016a). Проте є низка проблем у цій технології. Головною проблемою є градація електричної активності мозку та іï топіка. Стійке відтворення та ефективна ідентифікація цих патернів, на думку дослідників, сприятиме формуванню алфавіту керівних команд для нейроінтерфейсу і проблема градації електричної активності мозку частково вирішиться. Натомість інші дослідники повідомляють про відмінності у формуванні концептуальної обробки візуальних образів у мовних ділянках кори мозку (Louwerse, \& Hutchinson, 2012). Ще одна проблема це те, що в кожної людини через відмінність анатомії мозку i своєрідність вищих психічних функцій ЕЕГ патерни інколи бувають 
відмінними. Немає універсальних кодів, а також наявна 5\% похибка у розшифруванні кодів (Clerc, Bougrain \& Lotte, 2016b). Все вище сказане стосується команд коли думкою управляють комп'ютером чи машиною. Проте компанія EMOTIV на основі величезного емпіричного дослідження планетарного масштабу із застосуванням експертної оцінки психологів, ФМРТ, фіксації лицевої експресі та інших методів створили універсальні основні когнітивно-емоційні показники на основі ЕЕГ. Наприклад, на ЕЕГ у момент розпізнавання завченого образу, який є дуже життєво важливим у житті, ми фіксуємо у фронтальних відведеннях негативний, викликаний потенціал N100 після початку стимулу, комплекс N100-P200 та хвилю Р300. Більше того, якщо ми зафіксуємо пролонгацію хвилі P300 у P400 та Р500, то це ще свідчить про певні дії (в тому числі й мовлення як внутрішне так зовнішне) чи реальний намір діяти, спричинений цим образом (Yadava et al., 2017). Найбільшою діагностичною цінністю нейроінтерфейсу $\epsilon$ те, що він дозволяє психологу дізнатися про «внутрішню» емоцію незалежно від виразу обличчя людини, поведінки чи словесного висловлювання (Sourina \& Liu, 2011). Як бачимо нейроінтерфейс дозволяє дати не лише інтегральну оцінку ефективності та ефектності політичних гасел, а й дає змогу визначити об'єктивну психологістичну оцінку окремих у гаслі слів, які мають певне емоційне забарвлення для виборця і спонукатимуть діяти.

Для того, щоб виявити непомітне для звичайного спостереження у реакціях людей і здійснювати аналіз гасел не на припущеннях, а опиратися на факти, ми у своєму дослідженні застосували мобільний 14 канальний нейроінтерфейс «EMOTIV Ерос+». Крім того використали професійне програмне забезпечення для ЕЕГ моніторингу, для візуалізації електричної активності мозку та отримання трансформованих показників ЕЕГ у формі основних когнітивно-емоційних показників: EmotivPRO та EMOTIV Brain Activity Мар. Оновлення даних ЕЕГ підчас дослідження становило 128 раз на секунду.

\section{Результати та дискусії}

У 2018-2019 рр. гасла президентської виборчої кампанії мали сильну прив'язку до особистості кандидата на пост 
Президента. Головне завдання гасел - сформувати бренд особистості. Під брендом розуміють товар, послугу чи інформація, за яку людина свідомо готова переплачувати чи надати перевагу. У нейропсихології бренд розглядають як мультимодальний образ (веретеноподібна закрутка мозку) з емоційною прив'язкою (лімбічна система) (Ткач, 2018).

У сучасному світі існує безліч брендів і постійно з'являються нові й нові, а пропускна спроможність мозку до сприйняття інформації не збільшилася. Через це світові корпорації, публічні особистості, різні світоглядні системи між собою активно конкурують за нейрони для створення і постійного підтримання саме їнього мультимодального образу бренда, а не всіх загалом (Ткач, 2018). Процес бредування кандидата на пост Президента є інтеграцією процесів унікалізації та ідеалізації образу політика у свідомості електорату. По психологічних механізмах брендування ідентичне артифіціальній адитивній поведінці (Литвинчук, 2017). Це дуже важливий момент, що додає ясності при аналізі емоційного компоненту реакцій на електорату на гасла. Адже люди на момент дослідження вже зазнали потужного і тривалого інформаційного пливу з боку партійних маркетологів.

Інформація про дату, місце, умови дослідження та вибірку. Дата дослідження 12.11.2018. Місце проведення дослідження м. Львів. Дослідження проводилося у кабінеті психолога. Вибірка складалася 330 чоловіків і 30 жінок. Вік респондентів від 40 до 60 років. Вибірка формувалася 3 перехожих людей у місті стохастичним методом.

Варто зазначити, що у досліджуваній вибірці були лише ті люди, які мали намір прийти на вибори. Способом виявлення наміру прийти на вибори респондента було ствердна відповідь «так» та наявність високого рівня «взаємодії» (фіксація хвилі Р500 завдяки нейроінтерфейсу).

Інформація про представлення гасел для дослідження. 3 метою того, щоб дизайн гасел, шрифти, логотип партій чи сам кандидат у Президенти не впливав на когнітивно-емоційні показники, ми усі гасла представили чорним кольором та шрифтом Calibri на білому фоні. Це дозволило гасла подати як лінгвокогнітивний конструкт. У дослідження було включено всі політичні гасла, які 
були на зовнішній рекламі (біг-борди та сіті-лайти) 12.11.2018 у м. Львові. Уточнення щодо гасла: «Ми - Україна». Воно містило ще досить великий текст, який був дрібним шрифтом, і на відстані люди не могли його прочитати. Це ми виявили застосувавши окулограф 3 нейроінтерфейсом. Тому ми тестували лише те, що було читабельним для людей в реальних умовах. Експозиція гасел тривала 10 секунд.

У аналітичній таблиці 1 представлено результати емпіричного дослідження. Основні когнітивно-емоційні показники представлені по шкалі «від -5 до +5». Тобто ефект оцінюється по шкалі від максимального позитивного «+5», ніякого ефекту «0» та максимального негативного ефекту «-5». Рівень значимості зазначений у таблиці стосується гендерних відмінностей. У таблиці гасла ранговано - розташовані по спаданню ефективності.

Вважає за потрібне коротко висвітлити основні когнітивноемоційні показники від біометричної компанії «ЕMOTIV», які формуються на основі специфічних ЕЕГ патернів (Insight, 2017): Cтрес показує наскільки комфортно чи дискомфортно людині. Взаємодія визначає, наскільки людина занурюється у те, що робить чи переживає у даний момент. Інтерес відображає рівень цікавості людини до об'єкту. Хвилювання відображає рівень емоційного збудження (ажіотаж). Концентрація відображає наскільки людина зосередилася на даному завданні. Релаксація свідчить про рівень психічного спокою.

3 аналітичної таблиці стає зрозумілим, що жодне 3 гасел не $\epsilon$ цікавим i не $є$ ефективним у типового виборця. Спічрайтери та міфодизайнери які писали гасла не вміють створювати такі гасла, які б привертають увагу людей та через мову відображали очікувані для електорату складові образу та світу претендента на посаду Президента.

Ми з наявних гасел виокремити лідерів і аутсайдерів.

Найкращими гаслами, що спонукали лише підтримати є: «Ми - Україна» (найвищі показники взаємодії у чоловіків 59,2, у жінок 52,9), «Новий курс України» (взаємодії у чоловіків 49,5, у жінок 42,2), «Держава сильних!» (взаємодії у чоловіків 54,2, у жінок 41,6). До речі, хвилі Р300-500 виникали на слові «Україна». Це говорить про те, що серед населення присутні патріотичні почуття. 


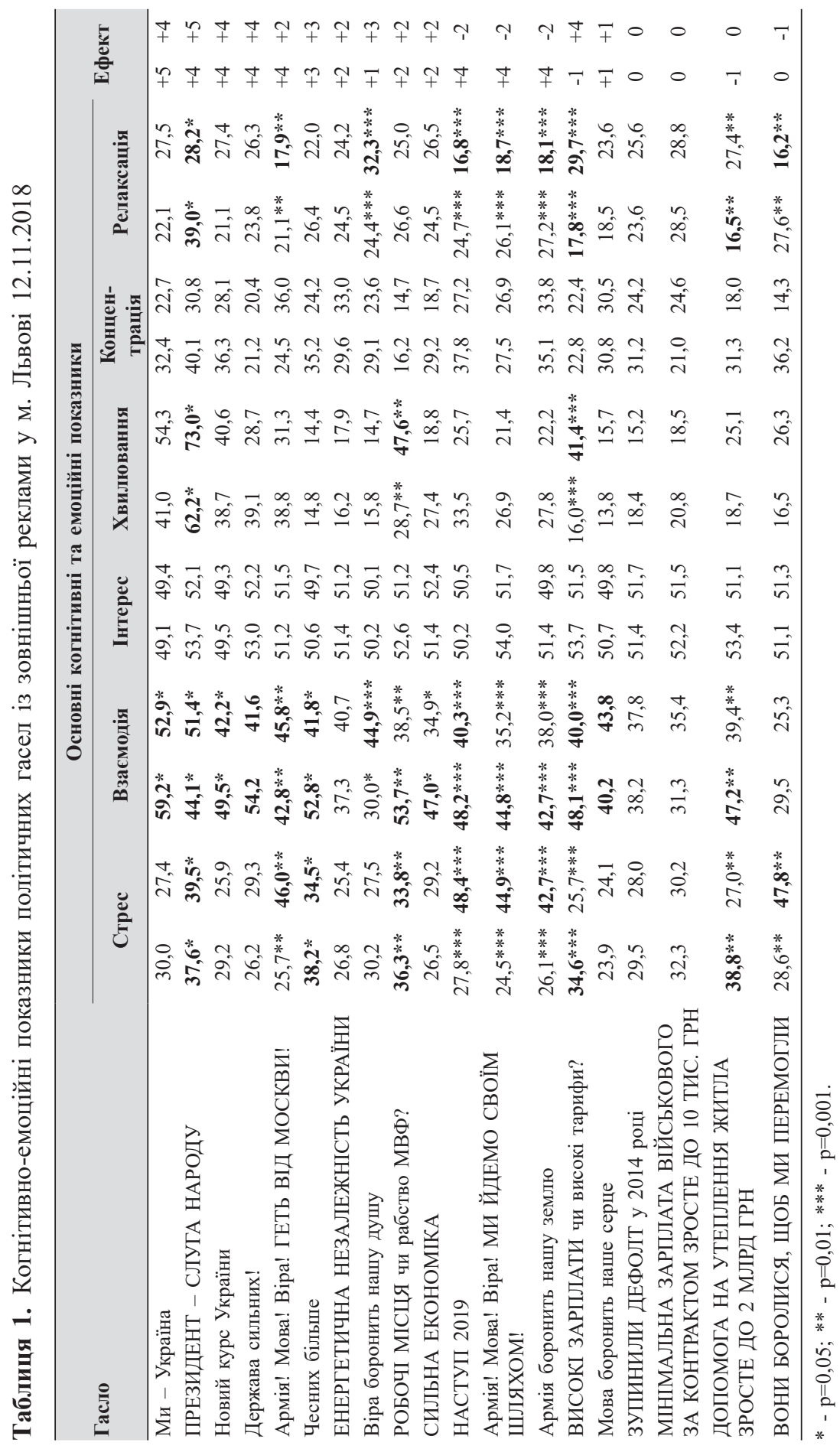


Neuro-Psycholinguistic Study of Political Slogans in Outdoor...

Найкращим ефектним і ефективним гаслом, що викликає позитивні емоції і реально спонукає підтримати є: «ПРЕЗИДЕНТ СЛУГА НАРОДУ». Про ефективність говорить високий показник взаємодії у чоловіків 44,1, а у жінок 51,4. Про ефективність свідчить ажіотаж (рівень хвилювання у чоловіків 62,2 і у жінок 73,0) та позитивні емоції, що відображається дещо підвищеним рівнем стресу (у чоловіків 37,6 і у жінок 39,5) у поєднанні з підвищеним рівнем релаксації (у чоловіків 39,0 і у жінок 28,2) Вважаємо, що успішність цього гасла перш за все пов'язане не з майстерністю підбору слів та семіотики, а з високою популярністю та професійною діяльністю у галузі сатири В. Зеленського. По своїй суті це гасло водночас є політичним і рекламним, що анонсує нову серію дуже популярного однойменного фільму у якому актор виконує роль чесного, некорумпованого і з народу Президента.

Безперечно хорошими гаслами є: «Армія! Мова! Віра! ГЕТЬ ВІД МОСКВИ!», «Чесних більше». Перше гасло завдяки віддаленню від реальної загрози (агресора) спонукає підтримати як чоловіків (рівень взаємодії 42,8), так і жінок (стрес 45,8). Проте слово «Армія» у жінок викликає сильний неспокій (високий показник стресу 46,0 i низький показник релаксації 17,9). Гасло «Чесних більше» спонукає підтримати (взаємодія у чоловіків 52,8 і у жінок 41,8), але викликає незначний стрес як у чоловіків $(38,2)$ так і жінок $(34,5)$. Мабуть, це пов'язане $з$ тим, що в існуючих «нечесних» обставинах девіантного контексту (дуже корумповане суспільство) людям доводиться задля виживання порушувати ціннісно-нормативні стандарти суспільства.

Посередніми гаслами є: «ЕНЕРГЕТИЧНА НЕЗАЛЕЖНІСТЬ УКРАЇНИ», «Віра боронить нашу душу», «РОБОЧІ МІСЦЯ чи рабство МВФ?» та «СИЛЬНА ЕКОНОМІКА». Гасло «ЕНЕРГЕТИЧНА НЕЗАЛЕЖНІСТЬ УКРАЇНИ» $€$ нейТраЛЬНИм 3 позитивом ухилом для всіх. Гасло «Віра боронить нашу душу» нейтральне з позитивом ухилом для чоловіків і водночас спонукає підтримати жінок (взаємодія 44,9). Гасло «РОБОЧІ МІСЦЯ чи рабство МВФ?» викликає незначний стрес у всіх (у чоловіків 36,3 і жінок 33,8), що пов'язано з дуже низькою оплатою праці, але спонукає підтримати чоловіків (взаємодія 53,7) і в той же час викликає емоційний підйом (хвилювання 47,6) у жінок. Гасло «СИЛЬНА ЕКОНОМІКА» нейтральне 3 позитивом для всіх i особливо спонукає підтримати чоловіків (взаємодія 47,0). 
Неоднозначними гаслами є: «НАСТУП 2019», «Армія! Мова! Віра! МИ ЙДЕМО СВОЇМ ШЛЯХОМ!», «Армія боронить нашу землю», «ВИСОКІ ЗАРПЛАТИ чи високі тарифи?». Перші три гасла спонукають підтримати всіх, але викликають значний неспокій у жінок (підвищений рівень стресу 42,7-48,4 і знижений рівень релаксації 16,8-18,7). Це пов'язано з армією і дуже вірогідною смертю власних дітей у збройному конфлікті на сході країни. Останнє гасло «ВИСОКІ ЗАРПЛАТИ чи високі тарифи?» спонукає підтримати всіх, але у чоловіків викликає неспокій (стрес 34,6), а у жінок релаксацію $(29,7)$. Вважаємо, що для чоловіків даного віку віднайти роботу з гідною зарплатою $є$ реальною проблемою. Натомість жінки мають вроджену схильність до розкішного та комфортного життя.

Малоефективне гасло: «Мова боронить наше серце». Це гасло спонукає підтримати всіх, але $\epsilon$ малоефективним. Найчастіше виникає реакція на слово «серце», ніж на слово «мова». Це пов'язано з тим, що у західній частині країні домінуючою $\epsilon$ українська мова і дане питання не викликає такого неспокою як у аборигенів східної частини країни.

Неефектні гасла: «ЗУПИНИЛИ ДЕФОЛТ у 2014 році», «МІНІМАЛЬНА ЗАРПЛАТА ВІЙСЬКОВОГО ЗА КОНТРАКТОМ ЗРОСТЕ ДО 10 ТИС. ГРН». Най індиферентне слово серед всіх гасел це «дефолт». Досліджуваним була не відома семантика цього слова. Крім того такий маркетинговий трюк як «знижка до ...» викликав відразу, тоді як слово «зарплата» підвищену увагу респондентів. Тому останнє гасло внутрішньою неузгодженістю саме себе нейтралізувало.

Були також гасла 3 негативним ефектом: «ДОПОМОГА НА УТЕПЛЕННЯ ЖИТЛА ЗРОСТЕ ДО 2 МЛРД ГРН», «ВОНИ БОРОЛИСЯ, ЩОБ МИ ПЕРЕМОГЛИ». Перше гасло нейтральне для жінок і водночас викликає стрес у чоловіків $(38,8)$. Дослідження проводилося на початку опалювального сезону і мабуть не всі чоловіки змогли фінансово чи організаційно забезпечити тепло у власних оселях. Останнє гасло є «ВОНИ БОРОЛИСЯ, ЩОБ МИ ПЕРЕМОГЛИ» нейтральним для чоловіків і стресовим $(47,8)$ для жінок. Дане гало відображало події столітньої давнини коли йшли визвольні змагання та намагання закріпити здобуту незалежність, 
Neuro-Psycholinguistic Study of Political Slogans in Outdoor...

проте на тлі збройного конфлікту у жінок викликало тривогу i відчуття несправедливості у призові до армії.

Результати нейропсихолінгвістичного дослідження проведеного за чотири місяці передбачили результати президентських виборів. Результати дослідження були оприлюднені 16.11 .18 у соцмережі «Феусбук» та 20.11.18 на телеканалі «Правда тут» у передачі «У полі азарту» випуск № 24.

\section{Висновки}

1. У західній частині України явно підвищує ефективність гасел наявність слова «Україна», оскільки це слово викликає позитивні емоції та патріотичні почуття, що спонукають людей діяти і реально боротися за власну незалежність.

2. Слова, які спричиняють неспокій у жінок $\epsilon$ армія і все, що пов'язане 3 насильством та смертю. Натомість у чоловіків слова, які спричиняють занепокоєння є все, що пов'язано із забезпеченням матеріальних благ і комфортними умовами існування.

3. У жінок західної частини країни значно виражена релігійна сентиментальність, яку можна вміло використовувати для спонукання жінок до бажаних дій на виборах.

4. Політичним маркетологам у процесі медіапланування мікротаргетингу необхідно обов'язково враховувати гендерні відмінності, бо як показало дослідження, гасла пов'язані 3 матеріальними ресурсами охоче підтримуються жінками i викликають стрес у чоловіків.

5. Також помітили, що одна команда «Порошенка» (президента України 2014-2019 рр.) створює гасла як ефективні так і не зовсім. Добре відомо, що одне негативне гасло нейтралізує решта позитивних. Тому наголошуємо, що ми вивчали вплив кожного гала окремо без прив'язки до політика.

6. Команда «Садового» (діючий мер м. Львова 32006 р.) створює неоднозначні та неефективні гасла.

7. Команда «Зеленського» (діючий Президент України 3 2019 р.) створила одне гасло «ПРЕЗИДЕНТ - СЛУГА НАРОДУ» (а точніше, модернізувала гасло радянської епохи «Депутат - слуга народу»). Проте ефектність та ефективність гасла зумовлене не семантикою слів, а успіхом однойменного фільму. 
8. Встановлено, що в суспільстві споживацтва нейропсихолінгвістичних засобів реорганізації основних когнітивноемоційних показників для створення ефективного психологічного впливу на поведінку виборця необхідно опиратися не на раціональну складову ідеології партії чи політичної програми, а на публічний імідж особистості і позитивні враження.

9. Нейропсихолінгвістичне дослідження дозволяє точно знати, що саме подобається виборцю і що саме у гаслі спонукає підтримати кандидата у електорату певного регіону. Це дозволяє коректувати контент політичної реклами, роблячи ï високоефективною, а це в свою чергу сприяє легкому досягненню успіху.

\section{Література}

Засєкіна, Л.В., \& Засєкін, С.В. (2008). Психолінгвістична діагностика. Луцьк: РВВ «Вежа» Волин. нац. ун-ту ім. Лесі Українки.

Литвинчук, Л.М. (2017). Психологія реабілітаиії наркозалежних осіб. (Монографія). Житомир : Вид-во ЖДУ ім. І. Франка.

Maksymenko, S.D. (2015). Genesis of Personality Existence: monography. Montreal: Accent Graphics Communication.

Максименко, С.Д., \& Орап, М.О. (2018). Психолінгвістичні предиктори здоров'я. Psycholinguistics. Психолінгвістика. Психолингвистика, 24(1), 252-268.

Ткач, Б.М. (2018). Нейропсихологія девіантної поведінки. (Монографія). Львів: ННВК «АТБ».

Absher, J.R., \& Cloutier, J. (2016). Neuroimaging Personality, Social Cognition, and Character. Amsterdam: Elsevier. https://doi.org/10.1016/B978-0-12-800935-2.00001-4

Churchland, P.S. (2013). Touching a Nerve: The Self as Brain. New York: W.W. Norton \& Company.

Clerc, M., Bougrain, L., \& Lotte, F. (Eds.). (2016a). Brain-Computer Interfaces 1: Methods and Perspectives. London: ISTE. https://doi.org/10.1002/9781119144977

Clerc, M., Bougrain, L., \& Lotte, F. (Eds.). (2016b). Brain-Computer Interfaces 2: Technology and Applications. London: ISTE. https://doi. org/10.1002/9781119332428

Dehaene, S. (2014). Consciousness and the Brain: Deciphering How the Brain Codes Our Thoughts. New York: Penguin Books.

Insight (2017). Emotiv. Retrieved from https://www.emotiv.com/insight/

Khushaba, R.N., Greenacre, L., Kodagoda, S., $\quad$ Louviere, J., Burke, S., \& Dissanayake, G. (2012). Choice modeling and the brain: A study on the Electroencephalogram (EEG) of preferences. Expert Systems with Applications, 39(16), 12378-12388. https://doi.org/10.1016/j.eswa.2012.04.084

Kolb, B., \& Whishaw, I.Q. (2015). Fundamentals of Human Neuropsychology (7th ed.). New York: Worth Publishers.

Louwerse, M., \& Hutchinson, S. (2012). Neurological evidence linguistic processes precede perceptual simulation in conceptual processing. Frontiers in psychology, 3, 385. https://doi.org/10.3389/fpsyg.2012.00385 
Nobre, K., \& Kastner, S. (2014). The Oxford Handbook of Attention. New York: Oxford University Press. https://doi.org/10.1093/oxfordhb/9780199675111.001.0001

Sourina, O., \& Liu, Y. (2011). A Fractal-based Algorithm of Emotion Recognition from EEG Using Arousal-Valence Model. In BIOSIGNALS - 2011. International Conference on Bio-inspired Systems and Signal Processing (pp. 209-214).

Westen, D. (2007). The Political Brain: The Role of Emotion in Deciding the Fate of the Nation. New York: Public Affairs Books.

Yadava, M., Kumar, P., Saini, R., Roy, P.P., \& Dogra, D.P. (2017). Analysis of EEG signals and its application to neuromarketing. Multimedia Tools and Applications, 76(18), 19087-19111. https://doi.org/10.1007/s11042-017-4580-6

\section{References}

Zasyekina, L.V., \& Zasyekin, S.V. (2008). Psyxolingvistychna diagnostyka [Psycholinguistic diagnostics]. Luczk: RVV «Vezha» Volyn. nacz. un-tu im. Lesi Ukrayinky [in Ukrainian].

Lytvynchuk, L.M. (2017). Psyxologiya reabilitaciyi narkozalezhnyx osib [Psychological Rehabilitation of Drug Addicted People]. Zhytomyr: Vyd-vo ZhDU im. I. Franka [in Ukrainian].

Maksymenko, S.D. (2015). Genesis of Personality Existence. Montreal: Accent Graphics Communication.

Maksymenko, S.D. (2018). Psiholingvistichni prediktori zdorovja [Psycholinguistic predictors of health]. Psiholingvistika - Psycholinguistics, 24(1). 252-268. https:// doi.org/10.31470/2309-1797-2018-24-1-252-268 [in Ukrainian].

Tkach, B.M. (2018). Nejropsyxologiya deviantnoyi povedinky [Neuropsychology of Deviant Behavior]. Lviv: NNVK «ATB».

Absher, J.R., \& Cloutier, J. (2016). Neuroimaging Personality, Social Cognition, and Character. Amsterdam: Elsevier. https://doi.org/10.1016/B978-0-12-800935-2.00001-4

Churchland, P.S. (2013). Touching a Nerve: The Self as Brain. New York: W.W. Norton \& Company.

Clerc, M., Bougrain, L., \& Lotte, F. (Eds.). (2016a). Brain-Computer Interfaces 1: Methods and Perspectives. London: ISTE. https://doi.org/10.1002/9781119144977

Clerc, M., Bougrain, L., \& Lotte, F. (Eds.). (2016b). Brain-Computer Interfaces 2: Technology and Applications. London: ISTE. https://doi. org/10.1002/9781119332428

Dehaene, S. (2014). Consciousness and the Brain: Deciphering How the Brain Codes Our Thoughts. New York: Penguin Books.

Insight (2017). Emotiv. Retrieved from https://www.emotiv.com/insight/

Khushaba, R.N., Greenacre, L., Kodagoda, S., Louviere, J., Burke, S., \& Dissanayake, G. (2012). Choice modeling and the brain: A study on the Electroencephalogram (EEG) of preferences. Expert Systems with Applications, 39(16), 12378-12388. https://doi.org/10.1016/j.eswa.2012.04.084

Kolb, B., \& Whishaw, I.Q. (2015). Fundamentals of Human Neuropsychology (7th ed.). New York: Worth Publishers.

Louwerse, M., \& Hutchinson, S. (2012). Neurological evidence linguistic processes precede perceptual simulation in conceptual processing. Frontiers in psychology, 3, 385. https://doi.org/10.3389/fpsyg.2012.00385 
Nobre, K., \& Kastner, S. (2014). The Oxford Handbook of Attention. New York: Oxford University Press. https://doi.org/10.1093/oxfordhb/9780199675111.001.0001

Sourina, O., \& Liu, Y. (2011). A Fractal-based Algorithm of Emotion Recognition from EEG Using Arousal-Valence Model. In BIOSIGNALS - 2011. International Conference on Bio-inspired Systems and Signal Processing (pp. 209-214).

Westen, D. (2007). The Political Brain: The Role of Emotion in Deciding the Fate of the Nation. New York: Public Affairs Books.

Yadava, M., Kumar, P., Saini, R., Roy, P.P., \& Dogra, D.P. (2017). Analysis of EEG signals and its application to neuromarketing. Multimedia Tools and Applications, 76(18), 19087-19111. https://doi.org/10.1007/s11042-017-4580-6

\section{АНОТАЦІЯ}

Вступ. У статті представлено результати нейропсихолінгвістичного дослідження із зовнішньої реклами. Розглянуто діагностичні можливості нейроінтерфейсу для оцінки ефективності гасел. Висвітлено процес орендування та існуючі методи оцінки ефективності. Показано специфіку нейропсихолінгвістики у підході до аналізу психічної діяльності особистості в засвоєнні та використанні мови. Метою дослідження є нейропсихолінгвістичне вивчення сприйняття електоратом політичних гасел із зовнішньої реклами; з'ясування того, що саме подобається виборцю $і$ що саме у гаслі спонукає підтримати кандидата у електорати певного регіону, що в свою чергу дозволить коректувати контент політичної реклами, роблячи ї̈ високоерективною.

Методи й методики дослідження. Для нейропсихолінгвістичного дослідження політичних гасел із зовнішньої реклами було використано мобільний 14 канальний нейроінтерфейс «ЕМОTIV Ерос+». Крім того, нами було використано професійне програмне забезпечення для ЕЕГ моніторингу з метою візуалізації електричної активності мозку та отримання трансформованих показників ЕЕГ у формі основних когнітивно-емоційних показників: EmotivPRO ma EMOTIV Brain Activity Мap. Рангування гасел по ефективності впливу на електорат було здійснено на основні сирих даних ЕЕГ та їх трансрормації у когнітивно-емоційні показники: стрес, взаємодія, інтерес, хвилювання, концентрація, релаксація. Даний комплекс нейропсихологівістичних методик $\epsilon$ релевантним виокремленим показникам. У дослідженні приймали участь потенційні виборці на президентських виборах 2019 року. Обсяг вибірки 30 чоловіків і 30 жінок.

Результати. Було встановлено, які саме гасла є найкращими, хорошими, посередніми, неоднозначними, малоефективними, неефектними та з негативним ефектом для виборців. Результати дослідження були оприлюднені 16.11.18 у соцмережі «Феусбук» та 20.11.18 на телеканалі «Правда тут» у передачі "У полі азарту» випуск № 24.

Висновки. Для створення ефективного психологічного впливу на поведінку вибория рекомендовано: наявність у гаслі слова "Україна», уникнення демотивуючих слів (для жінок це є армія і все, що пов'язане з насильством та 
смертю, а для чоловіків - все, що пов'язано із забезпеченням матеріальних благ), використання релігійної сентиментальності у жінок та врахування гендерних відмінностей при таргетингу гасел.

Ключові слова: політична реклама, гасло, досвід користувача, підсвідомі реакції, нейропсихолінгвістика, нейроінтерфейс, когнітивно-емоційні показники, електорат.

\title{
Максименко Сергей, Ткач Богдан, Литвинчук Олеся, Онуфриева Лиана. Нейропсихолингвистическое исследование политических лозунгов из внешней рекламы
}

\begin{abstract}
АННОТАЦИЯ
Вступление. В статье представлены результаты нейропсихолингвистического исследования политических лозунгов из внешней рекламы. Рассмотрены диагностические возможности нейроинтерфейса для оценки эффрективности лозунгов. Освещен процесс аренды и существующие методы оценки эфрективности лозунгов. Показана специфика нейропсихолингвистики в подходе к анализу психической деятельности личности в усвоении и использовании языка. Целью исследования является нейропсихолингвистическое изучение восприятия электоратом политических лозунгов из внешней рекламы; выяснение того, что именно нравится избирателю и что именно в лозунге побуждает поддержать кандидата в электорат определенного региона, что в свою очередь позволит корректировать контент политической рекламы, делая ее высокоэфрективной.
\end{abstract}

Методы и методики исследования. Для нейропсихолингвистического исследования политических лозунгов из внешней рекламы был использован мобильный 14 канальный нейроинтерфейс «ЕМОTIV Ерос+». Кроме того, использованы профессиональное программное обеспечение для ЭЭГ мониторинга с целью визуализации электрической активности мозга и получения трансформированных показателей ЭЭГ в форме основных когнитивно-эмоциональных показателей: EmotivPRO и EMOTIV Brain Activity Map. Ранжирование лозунгов по эффективности воздействия на электорат было осуществлено на основе сырых данных ЭЭГ и их трансформации в когнитивноэмоциональные показатели: стресс, взаимодействие, интерес, волнение, концентрация, релаксация. Данный комплекс нейропсихолингвистических методик является релевантным выделенным показателям. В исследовании принимали участие потенциальные избиратели на президентских выборах 2019 года. Объем выборки составляет 30 мужчин и 30 женщин.

Результаты. Было установлено, какие именно лозунги являются лучшими, хорошими, посредственными, неоднозначными, малоэффективными, неэффективними и с отрицательным эффректом для избирателей. Результаты исследования были обнародованы 16.11.18 в соцсети "Феусбук» и 20.11.18 на телеканале «Правда здесь» в передаче «В поле азарта» выпуск № 24. 
Выводы. Для создания эфрфективного психологического воздействия на поведение избирателя рекомендуется: наличие в лозунге слова "Украина", избежание демотивирующих слов (для женщин это слово "армия" и все, что связано с насилием и смертью, а для мужчин - все, что связано с обеспечением материальных благ), использование религиозной сентиментальности у женщин и учитывания гендерных различий при таргетинге лозунгов.

Ключевые слова: политическая реклама, лозунг, опыт пользователя, подсознательные реакции, нейропсихолингвистика, нейроинтерфейс, когнитивно-эмоциональные показатели, электорат. 